\title{
PERBEDAAN RERATA PENGETAHUAN TENTANG TUGAS PERKEMBANGAN REMAJA PADA WANITA MENIKAH USIA DINI DENGAN MENIKAH USIA MATANG DI KECAMATAN BANJARMASIN BARAT TAHUN 2018
}

(Knowledge Difference Regarding Adolescent Developmental Tasks Between Early Married And Mature Married Women In Banjarmasin Barat District Year 2018)

\author{
Syahrida Agustina*, Ruslinawati ${ }^{* *}$, Darmayanti ${ }^{\star \star *}$ \\ Program Studi S.1 Keperawatan \\ Fakultas Keperawatan dan IImu Kesehatan \\ Universitas Muhammadiyah Banjarmasin \\ Email: Syahridaagustina21@gmail.com \\ ruslinawati@umbjm.ac.id
}

\begin{abstract}
ABSTRAK
Remaja yang melakukan pernikahan dini secara perkembangan reproduksi dan psikologis belum matang karena masih mengalami masa transisi dari anak-anak menjadi pubertas. pernikahan dini dalam perspektif kesehatan reproduksi menemukan bahwa perempuan memiliki pengetahuan yang minim dan pemahaman yang kurang tentang dampak keputusan yang diambil untuk melakukan pernikahan dini. Semakin muda usia pernikahan maka akan semakin rendah pula jenjang pendidikan yang didapat, sehingga pengetahuan yang diperoleh juga akan semakin sedikit. Kecamatan Banjarmasin Barat mempunyai angka pernikahan dini tertinggi dari 5 Kecamatan yang ada di Kota Banjarmasin pada tahun 2017. Tujuan penelitian ini mengetahui perbedaan rerata pengetahuan tentang tugas perkembangan remaja pada wanita menikah usia dini dengan menikah usia matang di Banjarmasin Barat. Metode penelitian komparatif dengan pendekatan Cross Sectional menggunakan kuesioner dan uji statistik Independent t-test. Populasi berjumlah 172 wanita dengan sampel 63 responden terdiri dari 31 wanita menikah usia dini dan 32 wanita menikah usia matang yang menggunakan Cluster Random Sampling. Pada wanita menikah usia dini umur 15-20 tahun rerata pengetahuan didapatkan skor 52,58 sedangkan wanita menikah usia matang umur 21 25 tahun dapat rerata skor 69,31. Terdapat perbedaan rerata pengetahuan tentang tugas perkembangan remaja 16,73 $(\rho=0,000<\alpha=0,05)$.
\end{abstract}

Kata kunci : Pengetahuan, Pernikahan, Tugas Perkembangan Remaja

\begin{abstract}
Adolescents who carry out early marriage are reproductively and psychologically immature because they are still transitioning from childhood to puberty. Early marriage, in the reproductive health perspective, makes women have lacks of knowledge and lacks of understanding of its negative impacts. The younger the age of marriage, the lower the level of education obtained, so that the knowledge gained will also be less. Banjarmasin Barat district has the highest early marriage rate among 5 districts in Banjarmasin according to the data in 2017. The purpose of this study is to measure the knowledge differences regarding the adolescent developmental tasks between early married and mature married women in Banjarmasin Barat. A comparative research method using a cross-sectional approach was employed by utilizing a questionnaire for the data collection and Independent $t$-test for the data analysis. The sampling method used was cluster random sampling. There were 63 respondents of 172 populations in this study, consisting of 31 early married women and 32 mature married women. In the early marriage group, the women married at the age between 15-20 years old and the mean score obtained regarding the adolescent developmental tasks was 52.58. Meanwhile, the mature married women, who married between the age 21-25 years old, had a mean score of 69.31. There is a significant difference in the mean score of knowledge regarding the adolescent developmental tasks, which was $16.73(\rho=0,000<\alpha=0.05)$.
\end{abstract}

Keywords: Knowledge, Marriage, Adolescent Developmental Tasks 


\section{PENDAHULUAN}

Menurut Badan Kependudukan dan Keluarga Berencana Nasional (BKKBN), pernikahan dini atau menikah usia muda (early marriage) merupakan pernikahan yang dilakukan oleh sepasang remaja laki-laki dan perempuan dibawah usia 20 tahun yang seharusnya belum siap untuk menjalankan kehidupan rumah tangga. Usia menikah minimal perempuan 21 tahun dan laki-laki 25 tahun (BKKBN, 2017).

Pelaku pernikahan dini adalah remaja yang mengalami perkembangan dari masa kanak-kanak menjadi dewasa atau pubertas (Sarwono, 2013). Padahal remaja putri secara fisik organ reproduksinya belum sempurna dan belum matang secara psikologis (Murcahya, 2010 \& Cahyani, 2015). Penelitian tentang pernikahan dini dalam perspektif kesehatan reproduksi menemukan bahwa perempuan memiliki pengetahuan yang minim dan pemahaman yang kurang tentang dampak keputusan yang diambil untuk melakukan pernikahan dini (Susilo \& Awatiful, 2014). Selain wanita menikah usia dini, ada juga yang wanita menikah usia matang (Sumbulah \& Jannah, 2012). Menurut Erikson, usia matang sudah melewati tahap-tahap perkembangan yang ada pada usia sebelumnya yaitu usia remaja yang sedang mempersiapkan pernikahan sehingga individu lebih siap untuk berkeluarga (Permatasari, 2014).

Berdasarkan data United Nations Development Economic and Social Affairs (UNDESA), disebutkan bahwa Indonesia mengalami stagnasi dari tahun 2015 hingga 2017 dengan kejadian yang tergolong tinggi yaitu dari jumlah total 66,3 juta jiwa remaja, sebesar $34 \%$ atau 22,5 juta jiwa remaja yang melakukan pernikahan dini. Indonesia menempati urutan ke 37 dari 158 negara di dunia tentang pernikahan usia dini, sedangkan pada urutan Association of South East Asia Nations (ASEAN), Indonesia menempati urutan ke dua setelah negara Kamboja (Ekawati \& Kiki, 2017).

Menurut Riset Kesehatan Dasar (Riskesdas) 2013 menunjukan bahwa umur pertama menikah di Indonesia sudah cukup tinggi dengan usia 1519 tahun sebanyak 41,9 \% (Balitbangkes RI, 2013). Fakta di Indonesia bahwa provinsi dengan presentase pernikahan dini umur 15-19 tahun tertinggi adalah Kalimantan Tengah (52,1\%), Jawa Barat $(50,2 \%)$, Kalimantan Selatan $(48,4 \%)$, Bangka Belitung (47,9\%), dan Sulawesi Tengah (46,3\%) (BKKBN, 2014).
Hasil survei dari BKKBN Provinsi Kalimantan Selatan tahun 2015-2017 bahwa Kabupaten Kota Banjarmasin masuk 3 besar kabupaten tertinggi remaja putri dengan usia nikah pertama kurang dari 21 tahun dan kecamatan yang tertinggi Banjarmasin Barat dengan angka pernikahan dini 31\% (BKKBN, 2017). Berdasarkan data sekunder dari Kantor Urusan Agama (KUA) Banjarmasin Barat, jumlah remaja putri yang menikah di usia 15-19 tahun 2016 sebesar 26,3\%. Pada tahun 2017 sebesar 30,6\%. Sedangkan tahun 2018 bulan Januari dan Februari sebesar $21,8 \%$.

Studi pendahuluan yang dilakukan dari tanggal 9-11 juli 2018 bahwa pelaksanaan pernikahan dari bulan November 2017-Februari 2018 di KUA Banjarmasin Barat terdapat 31 wanita (18\%) dengan usia pernikahan 16-19 tahun dan 141 wanita (82\%) dengan usia pernikahan 21-29 tahun. Hasil wawancara kepada petugas KUA bahwa wanita yang menikah masih ada yang usia di bawah 20 tahun. Mereka mengijinkan wanita tersebut menikah dengan menegaskan syarat persetujuan orang tua, usia dituakan dari kartu tanda penduduk (KTP) dan menyarankan untuk menunda kehamilan sampai usia 20 tahun. Selain itu, pasangan pernikahan dini ada juga yang melakukan perceraian karena berbagai faktor tetapi pencatatannya dilakukan di pengadilan agama. Sedangkan wanita menikah usia dini dari 31 orang, dimana 3 orang diantaranya diambil sebagai sampel studi pendahuluan. Mereka menjelaskan alasan menikah dini karena 2 orang mengatakan dijodohkan oleh orangtua, namun mereka masih meminta uang dengan orangtua karena tidak memiliki pekerjaan dan 1 orang mengatakan karena keinginan dia sendiri akibat terlalu lama berpacaran yang membuat dia takut kehilangan pasangannya. Tiga wanita tersebut berusia 16-17 tahun yang tugasnya duduk dibangku sekolah dan belajar, bukan menjadi seorang ibu rumah tangga. Mereka seharusnya masih bergaul dengan teman sebayanya dan masih terjadi krisis identitas sehingga emosinya belum stabil. Kemudian wanita menikah usia matang dari 141 orang, dimana 3 orang diantaranya diambil sebagai sampel studi pendahuluan. Ketiga wanita tersebut berusia 2425 tahun. Mereka mengatakan alasan menikah karena ingin menyelesaikan pendidikan di perguruan tinggi namun hanya 1 orang yang sudah memiliki pekerjaan selain menjadi ibu rumah tangga dan 2 orang masih meminta uang saku pada orangtua karena belum bekerja. 
Seorang wanita harusnya melewati tahapan masa remajanya khususnya mempersiapkan pernikahan dan kehidupan berkeluarga agar lebih siap membina rumah tangga. Melihat dari latar belakang tersebut, peneliti tertarik untuk meneliti perbedaan rerata pengetahuan tentang tugas perkembangan remaja pada wanita menikah usia dini dengan menikah usia matang di Kecamatan Banjarmasin Barat tahun 2018.

\section{METODE PENELITIAN}

Jenis penelitian komparatif dengan pendekatan cross-sectional. Populasi berjumlah 172 wanita dengan sampel 63 responden terdiri dari 31 wanita menikah usia dini dan 32 wanita menikah usia matang yang menggunakan Cluster Random Sampling. Instrumen penelitian menggunakan kuesioner yang terdiri dari 32 butir pertanyaan tentang tugas perkembangan remaja. Penelitian ini telah lulus uji etik penelitian dengan nomor 130/UMB/KE/IX/2018. Pengumpulan data di Kecamatan Banjarmasin Barat dilakukan dengan cara door to door selama 4 minggu bulan Oktober. Pembagian kuesioner kepada sampel penelitian rata-rata 1-3 orang perhari. Pelaksanaan penelitian dengan memberikan penjelasan informed consent kurang lebih 10 menit dan pengisian kuesioner dengan waktu kurang lebih 30 menit. Variabel independen penelitian ini adalah pengetahuan wanita tentang tugas perkembangan remaja. Penelitian ini menggunakan uji statistik Independent $T$-Test dengan asumsi data homogen menggunakan Levene Test ( $P$-Value/Sig. $0,240>0,05)$

\section{HASIL DAN PEMBAHASAN}

\section{Hasil Penelitian}

Jumlah sampel dalam penelitian ini sebanyak 63 orang terdiri dari 32 wanita menikah usia matang dan 31 wanita menikah usia dini. Karakteristik responden penelitian dapat dilihat pada tabel berikut.

a. Tabel Distribusi Responden di Kecamatan Banjarmasin Barat Tahun 2018

\begin{tabular}{lcccccc}
\hline Karakteristik & \multicolumn{2}{c}{$\begin{array}{c}\text { Wanita } \\
\text { Menikah } \\
\text { Usia Dini }\end{array}$} & \multicolumn{2}{c}{$\begin{array}{c}\text { Wanita } \\
\text { Menikah Usia } \\
\text { Matang }\end{array}$} & Jumlah \\
& $\mathrm{F}$ & $\%$ & $\mathrm{~F}$ & $\%$ & $\mathrm{~F}$ & $\%$ \\
\hline Umur & & & & & & \\
$\mathbf{1 5 - 1 7}$ tahun & 5 & 16,12 & 0 & 0 & 5 & 7,94 \\
$\mathbf{1 8 - 2 0}$ tahun & 26 & 83,87 & 0 & 0 & 26 & 41,26 \\
$\mathbf{2 1 - 2 5}$ tahun & 0 & 0 & 32 & 100 & 32 & 50,80 \\
$\quad$ Total & 31 & 100 & 32 & 100 & 63 & 100 \\
\hline Kelurahan & & & & & & \\
Basirih & 6 & 19,35 & 2 & 6,25 & 8 & 12,70 \\
Teluk Tiram & 5 & 16,12 & 4 & 12,5 & 9 & 14,30 \\
Telaga Biru & 3 & 9,67 & 4 & 12,5 & 7 & 11,12 \\
Telawang & 8 & 25,80 & 4 & 12,5 & 12 & 19,04 \\
\hline
\end{tabular}

journal.umbjm.ac.id/index.php/midwiferyandreproduction

\begin{tabular}{|c|c|c|c|c|c|c|}
\hline Pelambuan & 4 & 12,90 & 3 & 9,37 & 7 & 11,12 \\
\hline Kuin Selatan & 1 & 3,22 & 3 & 9,37 & 4 & 6,34 \\
\hline Belitung & 1 & 3,22 & 4 & 12,5 & 5 & 7,93 \\
\hline \multicolumn{7}{|l|}{ Utara } \\
\hline Belitung & 1 & 3,22 & 4 & 12,5 & 5 & 7,93 \\
\hline \multicolumn{7}{|l|}{ Selatan } \\
\hline Kuin Cerucuk & 2 & 6,45 & 4 & 12,5 & 6 & 9,52 \\
\hline Total & 31 & 100 & 32 & 100 & 63 & 100 \\
\hline \multicolumn{7}{|l|}{ Pendidikan } \\
\hline SD & 11 & 35,48 & 0 & 0 & 11 & 17,46 \\
\hline SMP & 15 & 48,38 & 6 & 18,75 & 21 & 33,33 \\
\hline SMA & 5 & 16,12 & 11 & 34,37 & 16 & 25,39 \\
\hline Perguruan & 0 & 0 & 15 & 46,87 & 15 & 23,80 \\
\hline \multicolumn{7}{|l|}{ Tinggi } \\
\hline Total & 31 & 100 & 32 & 100 & 63 & 100 \\
\hline \multicolumn{7}{|l|}{ Pekerjaan } \\
\hline $\begin{array}{l}\text { Ibu Rumah } \\
\text { Tangga }\end{array}$ & 20 & 64,51 & 21 & 65,62 & 41 & 65,07 \\
\hline Swasta & 11 & 35,48 & 11 & 34,37 & 22 & 34,92 \\
\hline Total & 31 & 100 & 32 & 100 & 63 & 100 \\
\hline \multicolumn{7}{|l|}{ Jumlah Saudara } \\
\hline 1 & 0 & 0 & 1 & 3,12 & 1 & 1,58 \\
\hline 2 & 4 & 12,90 & 8 & 25 & 12 & 19,04 \\
\hline 3 & 7 & 22,58 & 11 & 34,37 & 18 & 56,25 \\
\hline 4 & 9 & 29,03 & 8 & 25 & 17 & 53,12 \\
\hline 5 & 11 & 35,48 & 4 & 12,5 & 15 & 46,87 \\
\hline Total & 31 & 100 & 32 & 100 & 63 & 100 \\
\hline \multicolumn{7}{|l|}{ Anak Keberapa } \\
\hline $\mathrm{Ke}-1$ & 17 & 54,83 & 15 & 46,87 & 32 & 50,79 \\
\hline $\mathrm{Ke}-2$ & 8 & 25,80 & 10 & 31,25 & 18 & 28,57 \\
\hline $\mathrm{Ke}-3$ & 4 & 12,90 & 6 & 18,75 & 10 & 15,87 \\
\hline $\mathrm{Ke}-4$ & 2 & 6,45 & 1 & 3,12 & 3 & 4,76 \\
\hline $\mathrm{Ke}-5$ & 0 & 0 & 0 & 0 & 0 & 0 \\
\hline Total & 31 & 100 & 32 & 100 & 63 & 100 \\
\hline
\end{tabular}

Berdasarkan tabel distribusi responden dapat diketahui, masih terdapat wanita menikah usia dini pada umur antara 15-17 tahun (16,12\%), sedangkan wanita menikah usia matang umur antara 21-25 tahun (100\%). Responden bertempat tinggal terbanyak di Kelurahan Telawang dan Basirih. Pendidikan wanita menikah usia dini di dominasi tingkat SMP $(48,38 \%)$, sedangkan wanita menikah usia matang di dominasi tingkat Perguruan Tinggi (46,87\%). Kebanyakan responden bekerja sebagai ibu rumah tangga dengan jumlah 41 orang $(65,07 \%)$. Wanita menikah usia dini kebanyakan memiliki jumlah saudara 5 orang $(35,48 \%)$, sedangkan wanita menikah usia matang kebanyakan 3 orang $(34,37 \%)$. kebanyakan responden menjadi anak ke-1 dalam keluarganya yaitu sebanyak 32 orang $(50,79 \%)$.

b. Grafik Distribusi Frekuensi Pengetahuan Wanita Menikah Usia Dini Dengan Menikah Usia Matang Berdasarkan tugas perkembangan remaja di Kecamatan Banjarmasin Barat Tahun 2018 


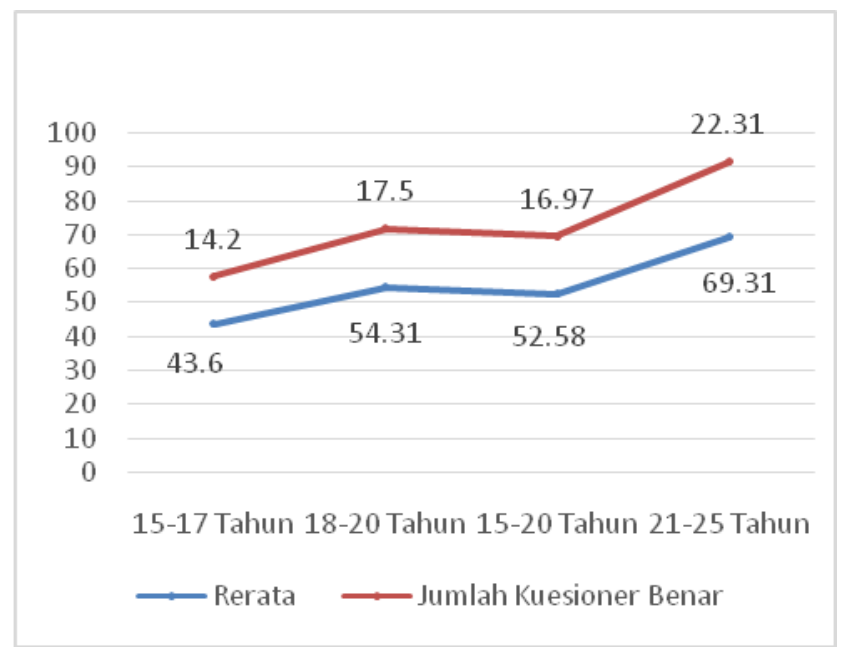

Berdasarkan grafik distribusi frekuensi pengetahuan diketahui bahwa, wanita menikah umur 15-17 tahun rerata (Mean) responden dapat menjawab 14,20 butir pertanyaan jawaban yang benar dengan skor 43,60, wanita umur 18-20 tahun rerata (Mean) responden dapat menjawab 17,50 butir pertanyaan jawaban yang benar dengan skor 54,31, wanita umur 15-20 tahun rerata (Mean) responden dapat menjawab 16,97 butir pertanyaan jawaban yang benar dengan skor 52,58 dan wanita umur 21-25 tahun rata-rata (Mean) responden dapat menjawab 22,31 butir pertanyaan jawaban yang benar dengan skor 69,31.

c. Tabel Analisis Uji Beda Rerata Pengetahuan tentang Tugas Perkembangan Remaja pada Wanita Menikah Usia Dini dengan Menikah Usia Matang

\begin{tabular}{cccccc}
\hline \multicolumn{2}{l}{$\begin{array}{l}\text { Levene's Test } \\
\text { for Equality of } \\
\text { Variances }\end{array}$} & \multicolumn{4}{c}{ t-test for Equality of Means } \\
\hline F & Sig. & T & Df & $\begin{array}{c}\text { Sig. (2- } \\
\text { tailed) }\end{array}$ & $\begin{array}{c}\text { Mean } \\
\text { Difference }\end{array}$ \\
& & & & then \\
$\mathbf{1 , 4 1 0}$ &, 240 & 7,808 & 61 &, 000 & 16,732 \\
\hline
\end{tabular}

Berdasarkan tabel analisis uji beda, nilai thitung adalah 7,808 , sedangkan t-tabel adalah $1,670(\alpha=0,05, N=63)$. Hasil tersebut menunjukkan, bahwa nilai t-hitung > nilai ttabel, maka Ho ditolak dan Ha diterima artinya ada perbedaan rerata pengetahuan tentang tugas perkembangan remaja pada wanita menikah usia dini dengan wanita menikah usia matang. Nilai $P$-Value/Sig. adalah $0,000<$ nilai a $(0,05)$, maka Ho ditolak dan $\mathrm{Ha}$ diterima artinya ada perbedaan rerata pengetahuan tentang tugas perkembangan remaja pada wanita menikah usia dini dengan wanita menikah usia matang.

\section{Pembahasan \\ Rerata pengetahuan wanita menikah usia dini tentang tugas perkembangan remaja.}

Rerata nilai pengetahuan wanita menikah usia dini umur 15-17 tahun dapat menjawab 14,20 butir pertanyaan jawaban yang benar dengan skor 43,60. Dilihat dari karakteristik responden masih ada responden yang berumur 15-17 tahun (16,12\%). Kondisi tersebut bisa terjadi karena menarche dini disebabkan pola hidup yang tidak sehat dan terpapar media sosial yang mengandung unsur seksual sehingga terjadi rangsangan terus-menerus yang mengakibatkan remaja memutuskan menikah dini. Dijelaskan oleh Bakkara et.al (2017) status ekonomi keluarga mempunyai peran yang cukup penting dalam percepatan usia menarche saat ini. Tingkat sosial ekonomi dikaitkan dengan kemampuan keluarga dalam hal kecukupan gizi keluarga terutama gizi anak perempuannya, kemampuan anak menikmati media cetak maupun media elektronik serta mengakses informasi budaya luar dan tingkat rangsangan psikis yang akhirnya akan berhubungan dengan usia menarche. Responden tersebut berada pada masa remaja pertengahan (Wong, 2009). Menurut Sarwono (2013) pada masa ini remaja berada dalam kondisi kebingungan karena tidak tahu harus memilih yang mana benar atau salah.

Sedangkan rerata wanita menikah usia dini umur 18-20 tahun dapat menjawab dengan benar 17,50 butir pertanyaan dengan skor 54,31 . Responden yang di dominasi berumur 18-20 tahun $(83,87 \%)$ dan berada pada masa remaja akhir. Seharusnya pada masa ini seseorang mengalami perkembangan menuju dewasa dan sudah mampu berfikir tentang masa depan. Akan tetapi hanya sebagian dari mereka yang mengetahui tentang tugas perkembangan remaja. Hal demikian bisa terjadi walaupun umur hampir dewasa tetapi pendidikan yang rendah akan menghambat menerima informasi.

Berdasarkan tingkat pendidikan responden di dominasi pada tingkat SMP (48,38\%), sebagian tingkat SD $(35,48 \%)$, dan hanya sedikit tingkat SMA (16,12\%). Pendidikan sangat diperlukan untuk mendapatkan informasi, mengembangkan kognitif, kepribadian dan sosial. Jika pendidikan seseorang rendah maka akan menghambat perkembangan tersebut. Selain itu, tingkat pendidikan juga sangat mempengaruhi mata pencaharian, semakin rendah pendidikan maka pekerjaan yang diperoleh akan semakin sulit. 
Hal ini sejalan dengan teori YB Mantra yang dikutip Notoatmodjo (2003), pendidikan dapat mempengaruhi seseorang termasuk juga perilaku seseorang akan pola hidup terutama dalam memotivasi untuk sikap berperan serta dalam pembangunan (Wawan \& Dewi, 2010).

Pekerjaan responden di dominasi sebagai ibu rumah tangga (64,51\%). Menurut Dewi (2012) salah satu tugas perkembangan remaja adalah memilih pekerjaan yang memerlukan kemampuan serta mempersiapkan pekerjaan. $\mathrm{Hal}$ ini harus dilakukan seseorang agar tidak ketergantungan dan mandiri dalam memenuhi kebutuhannya. Didukung pendapat Thomas yang dikutip oleh Nursalam (2003), pekerjaan adalah kebutuhan yang harus dilakukan terutama untuk menunjang kehidupannya dan kehidupan keluarganya (Wawan \& Dewi, 2010). Akan tetapi mereka hanya mengandalkan penghasilan suami dan menganggap tidak perlu lagi mencari pekerjaan atau mengalami kesulitan dalam hal keuangan karena sudah di tanggung suaminya.

Lingkungan sosial seperti keluarga mempengaruhi tugas perkembangan seseorang. Menurut Ann.Mariner, lingkungan merupakan suatu kondisi yang ada disekitar manusia dan pengaruhnya yang dapat mempengaruhi perkembangan dan perilaku orang atau kelompok (Wawan \& Dewi, 2010). Responden kebanyakan memiliki jumlah saudara 5 orang $(35,48 \%)$ dan menjadi anak ke-1 dalam keluarganya $(54,83 \%)$. Kelancaran tugas perkembangan juga banyak di pengaruhi oleh posisinya di tengah keluarga, sebagai anak tunggal atau bukan, anak kandung atau anak angkat, anak pertama atau terakhir (Maiyuniati, 2014).

Berdasarkan rekapitulasi butir kuesioner pada Lampiran 15, terdapat 13 butir pertanyaan dengan jawaban benar kurang dari $50 \%$, yaitu tugas hubungan dengan teman sebaya, tugas peran sosial, tugas kemandirian emosional, tugas kemandirian ekonomis, tugas persiapan pernikahan, tugas keterampilan intelektual, tugas tingkah laku yang bertanggung jawab dan tugas nilai pedoman hidup. Dapat disimpulkan bahwa dari 13 tugas perkembangan remaja tersebut terdapat beberapa masalah yang dialami dalam pemenuhan tugas-tugas perkembangan tersebut seperti masalah pribadi, yaitu masalah-masalah yang berhubungan dengan situasi dan kondisi di rumah, sekolah, kondisi fisik, penampilan, emosi, penyesuaian sosial, tugas dan nilai-nilai. Kemudian masalah khas remaja, yaitu masalah yang timbul akibat status yang tidak jelas pada remaja, seperti masalah pencapaian kemandirian, kesalahpahaman atau penilaian berdasarkan stereotip yang keliru, adanya hakhak yang lebih besar dan lebih sedikit kewajiban dibebankan oleh orangtua. Serta tugas-tugas perkembangan pada masa remaja yang disertai oleh berkembangnya kapasitas intelektual, stres dan harapan-harapan baru yang dialami remaja, membuat remaja mudah mengalami gangguan baik berupa gangguan pikiran, perasaan maupun gangguan perilaku (Santrock, 2012).

\section{Rerata pengetahuan wanita menikah usia matang tentang tugas perkembangan remaja.}

Rerata nilai pengetahuan responden dapat menjawab 22 butir pertanyaan jawaban yang benar dengan skor 69,31. Dilihat dari karakteristik responden yang dapat nilai rerata pengetahuan 69,31. Dari segi umur, semua responden berumur antara 21-25 tahun (100\%). Menurut Hurlock responden berada pada fase dewasa awal antara 20-40 tahun. Fase ini merupakan periode penyesuaian diri terhadap pola-pola kehidupan baru dan harapan baru, mengembangkan sikap-sikap baru, keinginankeinginan dan nilai-nilai baru sesuai dengan tugas-tugas baru. Ditambahkan oleh Erikson, bahwa usia dewasa sudah memiliki kematangan emosi karena sudah melewati tahap-tahap perkembangan remaja yang penuh gejolak (Permatasari, 2014). Oleh Lybertha \& Dinie (2016) dijelaskan masa dewasa awal merupakan masa seseorang untuk dapat memenuhi kebutuhan ekonomi dan kebutuhan pribadi secara mandiri.

Pekerjaan responden di dominasi sebagai ibu rumah tangga $(65,62 \%)$. Responden hanya mengandalkan penghasilan suami untuk memenuhi kebutuhan sehari-hari. Tetapi ada juga beberapa responden yang melakukan kerja swasta seperti wirausaha $(34,37 \%)$ untuk menambah penghasilan keluarga. Menurut Thomas yang dikutip oleh Nursalam pekerjaan adalah kebutuhan yang harus dilakukan terutama untuk menunjang kehidupannya dan kehidupan keluarganya. Pekerjaan bukanlah sumber mencari kesenangan, tetapi lebih banyak merupakan cara mencari nafkah yang membosankan, berulang, dan banyak tantangan (Wawan \& Dewi, 2010).

Walaupun pekerjaan responden di dominasi sebagai ibu rumah tangga tetapi tingkat pendidikan responden di dominasi 
lulusan perguruan tinggi (46,87\%). Pengetahuan itu sendiri dipengaruhi oleh faktor pendidikan formal. Pengetahuan sangat erat hubungannya dengan pendidikan, dimana diharapkan bahwa dengan pendidikan yang tinggi maka orang tersebut akan semakin luas pula pengetahuannya (Wawan \& Dewi, 2010).

Lingkungan sosial seperti keluarga mempengaruhi tugas perkembangan seseorang. Menurut Ann.Mariner, lingkungan merupakan suatu kondisi yang ada disekitar manusia dan pengaruhnya yang dapat mempengaruhi perkembangan dan perilaku orang atau kelompok (Wawan \& Dewi, 2010). Responden kebanyakan memiliki jumlah saudara 3 orang $(34,37 \%)$ dan menjadi anak ke-1 dalam keluarganya $(46,87 \%)$. Kelancaran tugas perkembangan juga banyak di pengaruhi oleh posisinya di tengah keluarga, sebagai anak tunggal atau bukan, anak kandung atau anak angkat, anak pertama atau terakhir (Maiyuniati, 2014). Ditambahkan oleh Hurlock (1980) urutan kelahiran mempengaruhi tugas perkembangan, misal anak pertama sering memiliki perasaan tidak aman, dan setelah dewasa cenderung menjadi "pengikut" dan lebih aktif kegiatan-kegiatan masyarakat dibandingkan anak yang lahir belakangan.

\section{Analisis perbedaan rerata pengetahuan tentang tugas perkembangan remaja pada wanita menikah usia dini dengan menikah usia matang.}

Rerata skor pengetahuan wanita menikah usia matang 69,31, lebih tinggi dibandingkan dengan wanita menikah usia dini 52,58. Hasil uji statistik penelitian ini juga menunjukkan, bahwa ada perbedaan rerata pengetahuan tentang tugas perkembangan remaja pada wanita menikah usia dini dengan wanita menikah usia matang (mean difference 16,732). Hal ini dibuktikan dengan nilai t-hitung sebesar $7,808>$ nilai t-tabel sebesar 1,670 dan juga nilai $P$-Value/Sig. adalah $0,000<$ nilai $\alpha(0,05)$.

Hasil penelitian ini hampir sama dengan penelitian yang pernah dilakukan oleh Aini (2015). Persamaannya adalah sama-sama membahas tentang pernikahan usia dini dengan usia matang. Dalam penelitiannya disimpulkan bahwa ada perbedaan pola asuh orang tua antara pasangan menikah di usia dini dan usia matang di Kecamatan Sewon Kabupaten Bantul Yogyakarta $P$-Value/Sig. adalah $0,002<$ nilai $\alpha(0,05)$. Selain itu, didukung juga oleh penelitian yang pernah dilakukan Permatasari (2014), dalam penelitiannya disimpulkan bahwa terdapat perbedaan kepuasan pernikahan pada istri yang menikah di usia remaja dan dewasa $P$. Value/Sig. adalah $0,001<$ nilai $\alpha(0,05)$. Kemudian ditambahkan oleh Muchlisah (2012), dalam penelitiannya menunjukkan ada perbedaan penyesuaian pernikahan antara perempuan yang menikah pada usia remaja dan usia dewasa di Kota Makasar P-Value/Sig. adalah $0,022<$ nilai $\alpha(0,05)$.

Dilihat dari karakteristik responden, wanita menikah usia dini dan wanita menikah usia matang memiliki latar belakang pendidikan yang berbeda sehingga terdapat perbedaan dalam mengetahui, memahami, mengapliksikan, menganalisis dan mengevaluasi sesuatu. Sebagaimana yang dikemukakan oleh Wawan dan Dewi (2010), bahwa pengetahuan merupakan hasil "tahu" dan ini terjadi setelah orang melakukan penginderaan terhadap suatu objek tertentu. Pengetahuan sangat erat hubungannya dengan pendidikan, dimana diharapkan bahwa dengan pendidikan yang tinggi maka orang tersebut akan semakin luas pula pengetahuannya.

Wanita menikah usia dini di dominasi berlatar belakang pendidikan pada tingkat SMP $(48,38)$ sedangkan wanita menikah usia matang di dominasi berlatar belakang pendidikan tingkat perguruan tinggi $(46,87)$. Pengetahuan akan mempengaruhi seseorang dalam hal bertindak atau bersikap. Pendidikan dapat mempengaruhi seseorang termasuk juga perilaku seseorang akan pola hidup terutama dalam memotivasi untuk sikap berperan serta dalam pembangunan. Nursalam dalam Wawan dan Dewi (2010) menegaskan, bahwa pada umumnya makin tinggi pendidikan seseorang makin mudah menerima informasi. Hal ini berarti semakin tinggi pengetahuan seseorang tentang tugas perkembangannya, maka akan semakin mudah dalam menerima, menerapkan dan mengevaluasi tugas perkembangan tersebut.

Kemudian dari segi umur, wanita menikah usia dini di dominasi umur 18-20 tahun $(83,87 \%)$ dan wanita menikah usia matang semuanya berumur 21-25 tahun (100\%). Walaupun secara umur wanita menikah usia dini hampir dewasa tetapi pendidikan yang rendah akan menghambat menerima informasi. Selain itu, mereka kurang kesempatan untuk mempersiapkan pernikahan dan kehidupan berkeluarga karena pernikahan dini. Sehingga secara psikologis wanita menikah usia dini mengembangkan sikap negatif terhadap 
kehidupan berkeluarga. Oleh Sarwono (2013) dijelaskan kesempatan merupakan peluang atau keadaan yang menunjukan tersedianya fasilitas dalam memenuhi tugas perkembangan remaja. Didukung penelitian Maiyuniati (2014) bahwa banyak sedikitnya kesempatan yang dimiliki remaja sangat berpengaruh pada pelaksanaan tugas perkembangan remaja. Ditambahkan hasil penelitian tentang pernikahan dini dalam perspektif kesehatan reproduksi bahwa perempuan memiliki pengetahuan yang minim dan pemahaman yang kurang tentang dampak keputusan yang diambil untuk melakukan pernikahan dini (Susilo \& Awatiful, 2014).

Sedangkan wanita menikah usia matang secara psikologis telah matang. Menurut Erikson, usia matang sudah melewati tahaptahap perkembangan yang ada pada usia sebelumnya yaitu usia remaja yang sedang mempersiapkan pernikahan sehingga individu lebih siap untuk berkeluarga (Permatasari, 2014). Wanita yang berusia 21-25 tahun merasa sudah siap membina bahtera rumah tangga dengan segala persoalannya dan biasanya orang dengan pendidikan tinggi cenderung menikah bukan pada saat usia masih muda karena cara berpikir mereka tidak lagi sama dengan orang-orang yang masih menganggap bahwa wanita segera menikah (Melisa, 2017).

Berdasarkan rekapitulasi butir kuesioner pada Lampiran 15, terdapat 23 butir pertanyaan yang membedakan nilai pengetahuan antara wanita menikah usia dini dengan menikah usia matang. Tugas hubungan dengan teman sebaya, wanita menikah usia matang $(75,00 \%)$ menjawab dengan benar pernyataan remaja mempelajari peran sebagai orang dewasa, sedangkan wanita menikah usia dini hanya $(54,83 \%)$. Secara psikologis, remaja putri lebih lambat matang daripada remaja putra merupakan pernyataan yang salah, wanita menikah usia matang dapat menjawab dengan benar $(59,37 \%)$ sedangkan wanita menikah usia dini hanya $(38,70 \%)$.

Tugas peran sosial, wanita menikah usia matang $(71,87 \%)$ menjawab dengan dengan benar pernyataan kekuatan fisik remaja putri lebih lemah dibandingkan remaja putra, sedangkan wanita menikah usia dini hanya $(54,83 \%)$. Pernyataan remaja putri cenderung tidak mengagumi ayahnya dan kakaknya merupakan pernyataan yang salah, wanita menikah usia matang dapat menjawab dengan benar $(59,37 \%)$ sedangkan wanita menikah usia dini hanya ( 19,35\%). Tugas keadaan fisik, pernyataan remaja tidak menerima dan memahami kondisi fisiknya merupakan pernyataan yang salah, wanita menikah usia matang dapat menjawab dengan benar $(78,12 \%)$, sedangkan wanita menikah usia dini hanya $(64,51 \%)$.

Tugas kemandirian emosional, pernyataan remaja ketergantungan dengan orang tua merupakan pernyataan yang salah, wanita menikah usia matang dapat menjawab dengan benar $(65,62 \%)$, sedangkan wanita menikah usia dini hanya $(38,70 \%)$. Kemudian pernyataan remaja yang tidak memperoleh kepuasan didalam keluarganya akan keluar untuk membangun ikatan emosional dengan teman sebaya, wanita menikah usia matang dapat menjawab dengan benar $(81,25 \%)$ sedangkan wanita menikah usia dini hanya (77,41\%). Remaja putri yang sudah menikah mengalami masa remaja yang diperpendek, sehingga ciri dan tugas perkembangan mereka juga ikut diperpendek dan masuk pada masa dewasa (Monks et.al, 2014). Kondisi ini terjadi karena remaja yang telah menikah akan mengalami suatu periode peralihan yang cukup signifikan. Mereka di haruskan masuk pada masa dewasa, tidak lagi pada ambang masa dewasa dan harus meninggalkan stereotip belasan tahun dan menjadi dewasa. Berbeda dengan masa dewasa awal, perkembangan dan pembentukan sikap dapat mencapai tingkat kematangan maksimum (Nurpratiwi, 2010). Wanita usia matang dapat berpikir positif dan memiliki kedewasaan menyelesaikan setiap masalah yang dihadapi. Selain itu, dengan matangnya usia seseorang maka mereka akan mampu mengambil keputusan atau pertimbangan-pertimbangan yang sehat dan berdasar dalam memutuskan suatu masalah, dapat menimbang baik dan buruk dalam ilmu yang memadai, serta dapat bersikap mandiri. Bila kematangan emosi dan usia telah matang dan didukung dengan cara berpikir yang baik sehingga akan dengan mudah menyelesaikan masalah-masalah yang terjadi dalam kehidupannya maka akan menciptakan kepuasan dalam pernikahannya.

Tugas kemandirian ekonomis, pernyataan remaja tidak mampu membangun kehidupannya sendiri merupakan pernyataan yang salah, wanita menikah usia matang dapat menjawab dengan benar $(65,62 \%)$ sedangkan wanita menikah usia dini $(38,70 \%)$. Kemudian wanita menikah usia matang dapat menjawab 
dengan benar $(62,50 \%)$ pada pernyataan remaja mulai mengembangkan kekuatan dan keterampilan fisik sedangkan wanita menikah usia dini hanya $(35,48 \%)$. Tugas persiapan bekerja, pernyataan remaja tidak memiliki kemampuan untuk bekerja merupakan pernyataan yang salah, wanita menikah usia matang dapat menjawab dengan benar $(59,37 \%)$ sedangkan wanita menikah usia dini hanya $(38,70 \%)$. Kemudian wanita menikah usia matang dapat menjawab dengan benar $(65,62 \%)$ pada pernyataan remaja usia 18 tahun merupakan usia yang matang untuk memperoleh lapangan pekerjaan, sedangkan wanita menikah usia dini hanya $(58,06 \%)$. Perbedaan pengetahuan wanita dari tugas kemandirian ekonomis dan persiapan bekerja, dipengaruhi oleh kreatifitas dan motivasi. Jika semakin tinggi, maka perkembangan kematangan kognitif akan semakin baik dan sebaliknya. Dijelaskan oleh Kumalasari (2013) banyak dari remaja yang menganggap kalau mereka menikah muda, tidak perlu lagi mencari pekerjaan atau mengalami kesulitan lagi dalam hal keuangan karena keuangan sudah ditanggung suaminya. Berbeda halnya dengan wanita menikah usia matang, dijelaskan oleh Melisa (2017) karier yang cemerlang membuat wanita merasa lebih bangga akan pencapaian pribadinya. Sebab karier yang cemerlang berarti jaringan pekerjaan yang lebih luas dan kemampuan diri sendiri yang lebih baik dari waktu ke waktu.

Tugas persiapan pernikahan, pernyataan remaja putri mengembangkan sikap negatif terhadap kehidupan berkeluarga merupakan pernyataan yang salah, wanita menikah usia matang dapat menjawab dengan benar $(62,50 \%)$ sedangkan wanita menikah usia dini hanya $(25,80 \%)$. Kemudian wanita menikah usia matang dapat menjawab dengan benar $(71,87 \%)$ pada pernyataan pernikahan merupakan suatu kebahagiaan hidup pada remaja putri, sedangkan wanita menikah usia dini hanya $(54,83 \%)$. Selanjutnya pada pernyataan remaja putri mempunyai ketertarikan seksual yang berlebih merupakan pernyataan yang salah, wanita menikah usia matang dapat menjawab dengan benar $(81,25 \%)$ sedangkan wanita menikah usia dini hanya $(25,80 \%)$.

Pernikahan merupakan suatu perjanjian saling mengikat antara laki-laki dan perempuan dengan suka rela untuk mewujudkan kebahagiaan dalam rumah tangga (Ramulyo, 2010). Melakukan pernikahan tanpa kesiapan dan pertimbangan yang matang dari satu sisi dapat mengindikasikan sikap tidak affresiatif terhadap makna nikah dan bahkan lebih jauh bisa merupakan pelecehan terhadap kesakralan sebuah pernikahan. Perubahan peran dari seorang perempuan yang sendiri menjadi istri yang siap mengurus rumah tangga adalah suatu tahap yang memang sangat membutuhkan penyesuaian. Terlebih lagi bila perannya berkembang menjadi seorang ibu, perlu adanya proses penyesuaian lagi. Dijelaskan oleh Satoto dalam Muchlisah (2012) bahwa penyesuian pernikahan dapat dipengaruhi oleh usia ketika menikah. Tingkat penyesuian perempuan yang menikah usia dewasa lebih tinggi dibandingkan penyesuaian pernikahan perempuan yang menikah pada usia remaja, hal ini dikarenakan remaja memiliki mental yang masih labil. Remaja cenderung masih mudah terpengaruh dengan kondisi disekelilingnya, belum mampu menyesuaikan diri dalam waktu singkat, bahkan memecahkan masalah-masalah yang akan dihadapi. Kondisi seperti itu menyebabkan cukup sulitnya remaja mengatasi segala persoalan yang terjadi di dalam pernikahannya.

Tugas keterampilan intelektual, pernyataan sistem syaraf dan otak remaja usia 14 tahun belum mencapai taraf ukuran dewasa merupakan pernyataan yang salah, wanita menikah usia matang dapat menjawab dengan benar $(71,87 \%)$ sedangkan wanita menikah usia dini hanya $(32,25 \%)$. Kemudian wanita menikah usia matang dapat menjawab dengan benar $(96,87 \%)$ pada pernyataan remaja mulai mempelajari wirausaha, sedangkan wanita menikah usia dini hanya (32,25\%).

Tugas tingkah laku bertanggung jawab, wanita menikah usia matang dapat menjawab dengan benar (100\%) pada pernyataan remaja berpartisipasi dalam sebuah kelompok, sedangkan wanita menikah usia dini hanya $(77,41 \%)$. Kemudian pada pernyataan remaja tidak menunjukkan sikap dewasa merupakan pernyataan yang salah, wanita menikah usia matang dapat menjawab dengan benar $(62,50 \%)$, sedangkan wanita menikah usia dini hanya $(29,03 \%)$. Selanjutnya pada pernyataan remaja memandang tingkah laku merupakan pengaruh dari perubahan dorongan psikologis merupakan pernyataan yang salah, wanita menikah usia matang dapat menjawab dengan benar $(65,62 \%)$ sedangkan wanita menikah usia dini hanya $(64,51 \%)$.

Tugas nilai pedoman hidup, pada pernyataan remaja tidak tertarik melaksanakan 
ibadah merupakan pernyataan yang salah, wanita menikah usia matang dapat menjawab dengan benar $(81,25 \%)$ sedangkan wanita menikah usia dini hanya $(64,51 \%)$. Kemudian wanita menikah usia matang dapat menjawab dengan benar $(87,50 \%)$ pada pernyataan remaja mengembangkan hubungannya dengan individu lain, sedangkan wanita menikah usia dini hanya $(51,61 \%)$. Selanjutnya pada pernyataan remaja cenderung tidak jujur dalam berbicara merupakan pernyataan yang salah, wanita menikah usia matang dapat menjawab dengan benar $(71,87 \%)$ sedangkan wanita menikah usia dini hanya $(45,16 \%)$. Terakhir pada pernyataan remaja sangat sopan santun dalam bertingkah laku, wanita menikah usia matang dapat menjawab dengan benar $(81,25 \%)$ sedangkan wanita menikah usia dini hanya $(25,80 \%)$.

\section{KESIMPULAN}

Berdasarkan hasil penelitian dan pembahasan pada 63 sampel di Kecamatan Banjarmasin Barat tahun 2018 terdiri dari 31 wanita menikah usia dini dan 32 wanita menikah usia matang, maka dapat disimpulkan sebagai berikut.

1. Wanita menikah usia dini (15-20 tahun) memiliki rerata pengetahuan (mean) skor 52,58 .

2. Wanita menikah usia matang (21-25 tahun) memiliki rerata pengetahuan (mean) skor 69,31 .

3. Ada perbedaan rerata pengetahuan tentang tugas perkembangan remaja pada wanita menikah usia dini dengan menikah usia matang $P$-Value/Sig. $(0,000<0,05)$.

\section{SARAN}

Hasil penelitian ini diharapkan dapat menjadi dasar atau kajian awal bagi peneliti lain yang ingin meneliti permasalahan yang sama sehingga mereka memiliki landasan dan alur yang jelas. Bagi peneliti selanjutnya yang berminat untuk meneliti mengenai tugas perkembangan remaja diharapkan dapat mempertimbangkan lebih banyak variabel yang dapat mempengaruhi tugas perkembangan remaja seperti lingkungan sosial, gambaran citra tubuh, motivasi, kepribadian, kesempatan untuk melaksanakan tugas perkembangan, bimbingan untuk mempelajari tugas perkembangan, kreatifitas, pemenuhan tugas perkembangan tahap sebelumnya, dukungan keluarga, dan posisi remaja dalam keluarga.

\section{DAFTAR RUJUKAN}

Aini, J. (2015). Perbedaan Pola Asuh Orang
Tua Antara Pernikahan
Matangdengan Usia Dini di Usia
Kecamatan Sewon Kabupaten Bantul
Yogyakarta. Skripsi. STIK Jenderal
Achmad Yani. Tersedia dalam
http://repository.unjaya.ac.id/ (diakses
tanggal 12 Agustus 2018).

Bakkara, R., Lukman, H., \& Suprapto. (2017). Faktor-Faktor Yang Berhubungan Dengan Menarche Dini Pada Remaja Putri Di SMPN 10 Kota Medan. Jurnal IImiah Kohesi. Vol.01, No.03, ISSN: $\quad 25795872 . \quad$ Tersedia dalam sciencemakarioz.org/ (diakses tanggal 2 januari 2019).

BKKBN. (2014). Pernikahan Dini Pada Beberapa Provinsi Di Indonesia. KRR: Jakarta.

(2017). Menekan Usia Dini Menikah. Jakarta Timur. BKKBN. Tersedia dalam https://keluargaindonesia.id// (diakses tanggal 22 juli 2018).

Cahyani, B. (2015). Dinamika Psikologis Perempuan Yang Melakukan Pernikahan

Di Usia Dini. Skripsi. Universitas Muhammadiyah Surakarta.Tersedia dalam http://eprints.ums.ac.id/ (diakses tanggal 7 juni 2018).

Dewi, H. E. (2012). Memahami Perkembangan Fisik Remaja. Yogyakarta: Gosyen Publishing.

Ekawati \& Kiki, I. (2017). Sikap Remaja Puteri Terhadap Pernikahan Dini Di Dusun Wonontoro Desa JatiayuKecamatan Karangmojo Kabupaten Gunung Kidul. JoH, Vol.4, No.1, hal: 35- 41. Tersedia dalam http://download.portalgaruda.org/ (diakses tanggal 18 juni 2018).

Hurlock, E.B. (1980). Development Psychology A Life-Span Approach. New York: McGraw-Hill.

Kumalasari. (2013). Kesehatan Reproduksi Untuk Mahasiswa Kebidanan dan Keperawatan. Jakarta: Salemba Medika. 
Lybertha, D.P \& Dinie, R.D. (2016). Kematangan Emosi Dan Persepsi Terhadap Pernikahan Pada Dewasa Awal: studi korelasi pada mahasiswa. Jurnal Empati. Vol.5, No.1, hal: 148-152. Tersedia dalam https://media.neliti.com/ (diakses tanggal 17 desember 2018).

Maiyuniati. (2014). Faktor Penyebab Kurang Lancarnya Remaja Awal Dalam Melaksanakan Tugas Tugas

Perkembangan Di SMP Negeri 25 Padang. Skipsi, STIKIP PGRI Sumatera Barat. Tersedia dalam http://download.portalgaruda.org/ (diakses tanggal 24 mei 2018).

Melisa. (2017). Alasan Wanita Modern Menikah di Usia Matang (Internet). Tersedia dalam https://kawaiibeautyjapan.com/article/ (diakses tanggal 24 Agustus 2018).

Monks, F.J., Knoers, A.M. P. \& Haditono, S.R. (2014). Psikologi Perkembangan Pengantar dalam berbagai bagiannya. Yogyakarta: Gadjah Mada University Press.

Murcahya, A. (2010). Dinamika Psikologis Pengambilan Keputusan Untuk Menikah Dini. Skripsi, Universitas Muhammadiyah Surakarta. Tersedia dalam http://eprints.ums.ac.id/ (diakses tanggal 7 juni 2018).

Muchlisah. (2012). Perbedaan Usia Wanita Ketika Menikah (Remaja danDewasa) dalam Hubungannya dengan Penyesuaian Pernikahan di Kota Masyarakat. Jurnal Psikologi. Vol.8, No.2, hal: 105-110. Tersedia dalam

http://download.portalgaruda.org/

(diakses tanggal 12 Agustus 2018).

Nurpratiwi, A. (2010). Pengaruh Kematangan Emosi dan Usia Saat Menikah Terhadap Kepuasan Pada Dewasa Awal. Skripsi, UIN Syarif Hidayatullah. Tersedia dalam http://repository.uinjkt.ac.id/ (diakses tanggal 18 desember 2018).

Permatasari, Y. (2014). Perbedaan Kepuasan Pernikahan Pada Istri yang Menikah

journal.umbjm.ac.id/index.php/midwiferyandreproduction di Usia Remaja dan Dewasa. Skripsi. Universitas Kristen Satya Wacana Salatiga. Tersedia dalam http://repository.uksw.edu/ (diakses tanggal 12 Agustus 2018).

Putro, K.Z. (2017). Memahami Ciri dan Tugas Perkembangan Remaja. Jurnal Aplikasi IImu-ilmu Agama. Vol.17, No.1, hal. 25-32, ISSN 14118777. Tersedia dalam ejournal.uin suka.ac.id/ (diakses tanggal 24 mei 2018).

Ramulyo, M.I. (2010). Hukum Perkawinan Islam (Suatu Analisis Dari Undang Undang Nomor 1 Tahun 1974 Dan Kompilasi Hukum Islam), Cet.Il. Jakarta: Bumi Aksara.

Rosmiati, Junias, D.T.S, \& Munawar. (2015). Sikap, Motivasi, dan Minat Berwirausaha Mahasiswa. JURNA MANAJEMEN DAN KEWIRAUSAHAAN. Vol.17, No.1, hal: 21-30, ISSN: 2338-8234. Tersedia dalam http://jurnalmanajemen.petra.ac.id/ (diakses tanggal 17 desember 2018).

Santrock, J.W. (2012). Life-span Development. 13 th Edition. University of Texas,Dallas : Mc Graw Hill.

Sarwono, W.S. (2011). Psikologi Remaja. Jakarta: PT Raja Grafindo Persada.

(2013). Psikologi Remaja. Jakarta: PT Raja Grafindo Persada.

Sumbulah, U. \& Jannah, F. (2012). Pernikahan Dini dan Implikasinya terhadap Kehidupan Keluarga pada Masyarakat Madura (Perspektif Hukum dan Gender). Jurnal Kesetaraan dan Keadilan Gender. Vol. VII, No. 1, hal: 83101. Tersedia dalam http://repository.uinmalang.ac.id/ (diakses tanggal 12 agustus 2018).

Susilo, C. \& Awatiful, A. (2014). Pernikahan Dini Dalam Persfektif Kesehatan Reproduksi. THE INDONESIAN JOURNAL OF HEALTH SCIENCE, Vol. 4, No. 2, hal: 112-121. Tersedia dalam http://digilib.unmuhjember.ac.id/ (diakses tanggal 8 juni 2018).

Wawan, A \& Dewi M. (2010). Teori dan Pengukuran Pengetahuan, Sikap, dan 
Perilaku Manusia. Yogyakarta : Nuha Medika.

Wong, L.D. (2009). Buku Ajar Keperawatan Pediatrik. Jakarta: EGC.
Yusuf, S. (2012). Psikologi Perkembangan Anak dan Remaja. Bandung: PT. Remaja Rosdakarya. 